\title{
The $\gamma$ phosphorylase kinase gene, Phkg, maps to mouse Chromosome 5 near Gus
}

\author{
A.J. Maichele, ${ }^{1}$ J.S. Chamberlain ${ }^{1,2}$

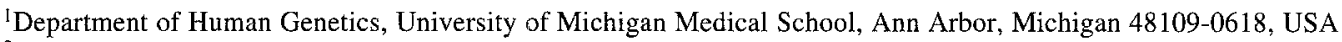 \\ ${ }^{2}$ Human Genome Center, University of Michigan Medical School, Ann Arbor, Michigan 48109-0618, USA \\ Received: 29 June 1993 / Accepted: 26 August 1993
}

\begin{abstract}
Phosphorylase kinase is a multimeric regulatory enzyme in the glycogenolytic pathway. Interest in various types of phosphorylase kinase enzyme deficiency has focused attention on cloning and mapping the enzyme subunits. We report the mapping of the catalytic $\gamma$ subunit gene, $P h k g$, to mouse Chromosome (Chr) 5 near $\beta$-glucuronidase $(G u s)$, between alpha fetoprotein $(A f p)$ and erythropoietin (Epo). In addition, PCR-based polymorphism assays have been developed for the human (EPO) and mouse erythropoietin genes, and a unique recombinant inbred strain distribution pattern has been defined for Epo, a distal anchor marker on mouse Chr 5 .
\end{abstract}

\section{Introduction}

Phosphorylase kinase (Phk) is an intermediate enzyme in the glycogenolytic regulatory cascade. This multimeric enzyme is activated by phosphorylation via the $\beta$-adrenergic pathway and by calcium ions released by neural stimulation. Activated Phk phosphorylates the enzyme glycogen phosphorylase, which releases glucose-6-phosphate from glycogen (reviewed by Picket-Gies and Walsh 1986). Tissue-specific isoforms of each of the Phk subunits have been described and presumably regulate the activity of the holoenzyme in various tissues. The regulatory subunits, $\alpha$ and $\beta$, have been cloned from rabbit and mapped in human and mouse (Zander et al. 1988; Francke et al. 1989; Barnard et al. 1990; Davidson et al. 1992; Harmann et al. 1991). A family of calmodulin genes to which the $\delta$ subunit belongs has also been cloned (Nojima 1989).

The gene encoding the skeletal muscle isoform of $\gamma \mathrm{Phk}$ $(P h k g)$ has been cloned from mouse and rat (Maichele et

Correspondence to: J.S. Chamberlain al. 1993; Cawley et al. 1993). In the current study we have identified polymorphisms in $P h k g$ and have used those markers to map the gene to mouse Chr 5 near $\beta$-glucuronidase $(G u s)$. A new polymorphism in the mouse erythropoietin (Epo) gene, a distal Chr 5 reference marker, was also developed for use in mapping with the recombinant inbred strain AKXL and with interspecific backcrosses. The linkage of Phkg to Gus and Epo in the mouse suggests human Chr 7q21-q22, which contains the human genes GUSB and EPO, as the most likely location for the human homolog, PHKG.

\section{Materials and methods}

Construction of the intersubspecific backcross (DF/B- $d f / d f \times$ CASA/Rk) $\times \mathrm{DF} / \mathrm{B}-d f / d f$, and isolation of DNA from these animals has been described previously (Buckwalter et al. 1991; Lossie et al. 1993). DNA from Mus musculus domesticus (strain WSB) was a gift from P. Tucker (University of Michigan). DNA from CASA/Rk, MOLD/Rk, Mus musculus musculus, Mus musculus domesticus poschiavinus, and the recombinant inbred strain AKXL was obtained from The Jackson Laboratory.

Polymerase chain reactions (PCR) were performed as previously described with one radiolabeled primer in each reaction (Maichele and Chamberlain 1992). Reaction products were analyzed on $6 \%$ denaturing polyacrylamide gels, followed by autoradiography. Primer sequences for Afp (Aitman et al. 1991), Gus (Hearne et al. 1991), and the Phkg B2 repeat insertion (Maichele et al. 1993) have been published. D5Mit27 oligonucleotide primers were purchased from Research Genetics and used at an annealing temperature of $55^{\circ} \mathrm{C}$ (Dietrich et al. 1992a, 1992b). Additional forward and reverse primers and annealing temperatures are as follows:

Phkg4A: $61^{\circ} \mathrm{C}$; F: GAC AAC AGT TGA TTC AGG GCC; R: TAA ACA ACC TCC CCC ACC C

Phkg4B: $61^{\circ} \mathrm{C}$; F: GAC ATG AAC TAC CAC CAG CAG C; R: GCT GGG ACT AAA GGT ATG GGC

Phkg4C: $60^{\circ} \mathrm{C}$; F: CTG TGA GAT TCA GAC CAG CCT G; R: GGG CTG AAT TAA AGG CAT GC

Epo: $59^{\circ} \mathrm{C}$; F: GTG TGG GAG AAA ATA TCA GAG ACA; R: AAT GTC ATT CCC TAT CCT CCC T 
A

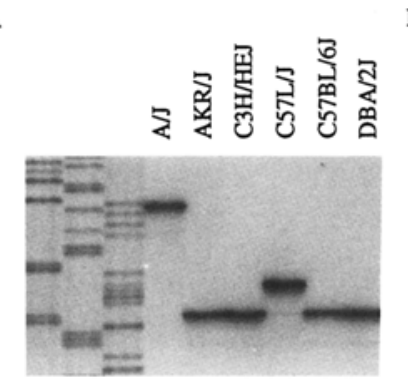

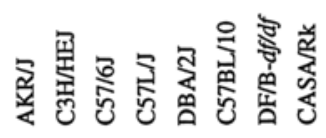

C

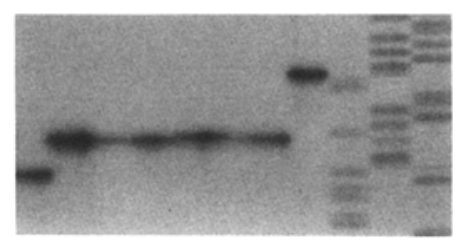

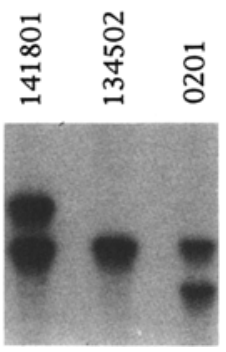

Fig. 1. The range of allele sizes in some of the RI parental strains at $P h k g 4 A$ (A) and Epo (B). Allele sizes were determined by reference to previously sequenced alleles and a one-base-pair ladder generated from pTZ19R (see Table 1). (C) The three EPO alleles in the CEPH parents.

Table 1. Strain genotypes at polymorphic loci within Phkg and Epo. Simple sequence repeats and B2 polymorphisms are described in the text. PCR products were amplified from genomic DNA from eight strains and seven species of mice and resolved on denaturing polyacrylamide gels. Sequencing ladders from pTZ19R were used in conjunction with PCR products from previously sequenced alleles as molecular size standards. AKR/J and C57L/J are the progenitors of recombinant inbred strain AKXL. $\mathrm{DF} / \mathrm{B}-d f / d f$ and CASA/Rk are the backcross parental strains.

\begin{tabular}{|c|c|c|c|c|c|c|c|c|c|c|c|c|c|c|c|}
\hline & ${ }_{B}{ }^{P}$ & (1) & $\sigma^{1 B}$ & $d j$ & $c^{3}+$ & $\rho^{\beta}$ & $\mathrm{cos}^{\circ}$ & $c^{5}{ }^{19}$ & $c^{0} \pi$ & N.m. & $\begin{array}{l}N^{S B} \\
n^{n}\end{array}$ & $\begin{array}{l}\mathrm{nos}^{\mathrm{s}^{\mathrm{C}}} \\
\mathrm{n}^{\mathrm{O}}\end{array}$ & $c^{s}$ & N. & $N w^{s} s e^{e^{r} w^{s}}$ \\
\hline$P h k g 4 A$ & 150 & 150 & 150 & 147 & 147 & 147 & 147 & 147 & 147 & 148 & 165 & 137 & a & 147 & $230-250$ variable $^{b}$ \\
\hline$P h k g 4 B$ & 105 & 105 & 105 & 108 & 108 & 108 & 108 & 108 & 108 & 108 & 104 & 106 & 93 & 99 & $103,116^{b}$ \\
\hline Phkg4C & 242 & 242 & 242 & 222 & 222 & 222 & 222 & 222 & 227 & 232 & 232 & 272 & 177 & 297 & $97,240,254,340,350$ \\
\hline Phkg exon 10 B2 & + & + & + & - & - & - & - & - & - & - & + & + & + & - & - \\
\hline Epo intron 3 & 163 & 163 & 163 & 159 & 163 & 163 & 163 & 163 & 163 & $c$ & c & 171 & 171 & $\mathrm{c}$ & a \\
\hline
\end{tabular}

a Did not amplify.

b Not all samples amplify.

c Not tested.

EPO: $59^{\circ} \mathrm{C}$; F: AAT GAG GGC TGT ATG GAA TAC A; R: AGC TGA GCA AAC AGA AGG TAT G

\section{Results and discussion}

\section{Polymorphic sequences in Phkg}

While characterizing the structure of Phkg, we observed several potentially polymorphic short tandem repeat (STR) sequences within intron 4 (Weber and May 1989; Hearne et al. 1991). These STRs had the sequences (AT) ${ }_{12} \mathrm{TC}(\mathrm{T})_{25}$, $(\mathrm{T})_{5} \mathrm{AT}(\mathrm{A})_{28}$, and (AAAGG) ${ }_{13}$, and were designated $P h k g 4 A, P h k g 4 B$, and $P h k g 4 C$, respectively. Gel analysis of PCR products amplified from genomic DNA of various strains of mice demonstrated that each of these repeats is polymorphic (Table 1, Fig. 1). The seven analyzed inbred strains exhibited three $P h k g$ haplotypes.

In addition to the STRs observed in intron 4 , we have identified a B2 repeat present in Phkg exon 10 of certain strains and species of mice. The presence or absence of this repeat can be assayed by PCR and is associated with differences in the relative sizes and amounts of the two transcripts produced from the gene (Table 1; Maichele et al. 1993). M. m. castaneus (CASA/Rk) and M. m. molossinus (MOLD/Rk) contain the insertion, whereas $M$. spretus does not. Of particular interest is the fact that strains of $M$. $m$. domesticus (WSB and poschiavinus) collected in various locations differ in the presence or absence of this repeat insertion (Table 1).

\section{Polymorphic sequences in Epo and EPO}

Epo recently replaced $Z p-3$ as the most distal Chr 5 backbone marker, based in part on the assumption that an STR was available for this locus (Kozak and Stephenson 1992). However, the original reference (Abbot 1992) described PCR primers that amplify a non-polymorphic sequence in the mouse Epo gene and that were used to screen mouse-hamster somatic cell hybrid panels for the presence of mouse Chr 5. While searching for potential polymorphisms, we observed an STR of sequence (TTCA) ${ }_{8}$ within intron 3 of the published Epo sequence (McDonald et al. 1986). PCR analysis showed that this STR would be informative in crosses between AKR/J and the other tested laboratory strains, as well as in intersubspecific crosses with CASA/Rk or MOLD/Rk (Table 1 and Fig. 1). This Epo STR also defines a unique strain distribution pattern (SDP) for distal Chr 5 in the recombinant inbred strain AKXL (Table 2, Fig. 2).

The human erythropoietin gene sequence (Lin et al. 1985) also contains an imperfect STR in intron 3, in this case following an Alu repeat. When examined by singlestrand conformation polymorphism (SSCP), this Alu repeat exhibited two alleles with a polymorphic information content (PIC value) of 0.06 (Orita et al. 1990; Botstein et al. 1980). To determine whether a more informative or easier to analyze polymorphism could be obtained by focusing directly on the STR, we used PCR primers flanking this region to amplify genomic DNA from $80 \mathrm{CEPH}$ parents. Three alleles were detected (Fig. 1); the most common probably corresponds to the previously sequenced 108-bp allele (Lin et al. 1985; Orita et al. 1990) and has a fre- 
Table 2. Strain distribution pattern of distal mouse Chr 5 loci typed in the AKXL RI strains. At each locus, alleles derived from AKR/J and C57L/J are represented by the letters $\mathrm{A}$ and $\mathrm{L}$, respectively.

\begin{tabular}{|c|c|c|c|c|c|c|c|c|c|c|c|c|c|c|c|c|c|c|c|}
\hline \multirow[b]{2}{*}{ Locus } & \multicolumn{18}{|c|}{ AKXL strains } & \multirow[b]{2}{*}{ References } \\
\hline & 5 & 6 & 7 & 8 & 9 & 12 & 13 & 14 & 16 & 17 & 19 & 21 & 24 & 25 & 28 & 29 & 37 & 38 & \\
\hline$P m v-11$ & $\mathrm{~L}$ & $\mathrm{~L}$ & L & $\mathrm{A}$ & $\mathrm{L}$ & A & $\mathrm{L}$ & A & $\mathrm{L}$ & A & A & $\mathrm{L}$ & $\mathrm{L}$ & $\mathrm{L}$ & $\mathrm{L}$ & $\mathrm{L}$ & $\mathrm{L}$ & A & Frankel et al. 1989 \\
\hline$B c d-I$ & $\mathrm{~A}$ & $\mathrm{~A}$ & $\mathrm{~L}$ & $\mathrm{~L}$ & $\mathrm{~L}$ & $\mathrm{~A}$ & $\mathrm{~A}$ & A & $\mathrm{A}$ & $\mathrm{L}$ & $\mathrm{L}$ & $\mathrm{L}$ & $\mathrm{L}$ & A & $\mathrm{L}$ & $\mathrm{L}$ & $\mathrm{L}$ & $\mathrm{L}$ & Winchester et al. 1987 \\
\hline Fla & L & A & $\mathrm{L}$ & A & $\mathrm{A}$ & $\mathrm{L}$ & A & A & A & A & $\mathrm{L}$ & $\mathrm{L}$ & $\mathrm{L}$ & $\mathrm{L}$ & $\mathrm{L}$ & L & $\mathrm{L}$ & $\mathrm{L}$ & Winchester et al. 1987 \\
\hline Gus, D5Mit27, Phkg & $\mathrm{L}$ & A & $\mathrm{L}$ & A & A & $\mathrm{L}$ & A & $\mathrm{A}$ & A & A & $\mathrm{L}$ & $\mathrm{L}$ & $\mathrm{L}$ & $\mathrm{L}$ & $\mathrm{L}$ & $\mathrm{L}$ & $\mathrm{L}$ & $\mathrm{L}$ & Winchester et al. 1987 ; this work \\
\hline Epo & A & A & $\mathrm{L}$ & A & A & $\mathrm{L}$ & A & A & A & $\mathrm{A}$ & $\mathrm{L}$ & A & A & $\mathrm{L}$ & $\mathrm{L}$ & $\mathrm{L}$ & A & A & This work \\
\hline
\end{tabular}

Distal mouse chromosome 5

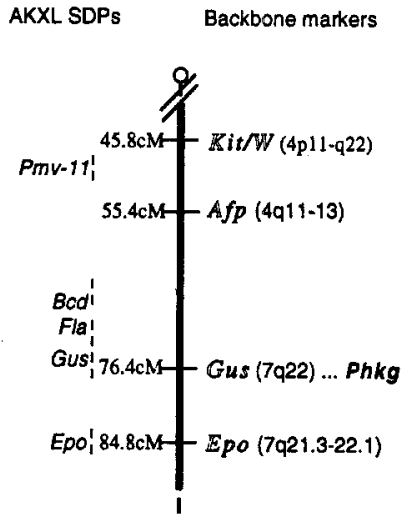

Fig. 2. Linkage map of distal mouse Chr 5 (after Kozak and Stephenson 1992). Backbone markers are shown in open typeface with the locations of their human homologs in parentheses and distances from the centromere to the left. The approximate locations of AKXL strain distribution patterns are shown in dotted lines. Human chromosomal locations are from: Kit, Hsieh et al. 1991; Afp, Theune et al. 1991; Gus, Allanson et al. 1988; Epo, Watkins et al. 1986; and Human Gene Mapping 11,1991 .

quency of 0.89 . A second allele is four base pairs longer and occurs with a frequency of 0.106 . CEPH DNA \# 141801 is heterozygous for those two alleles. A third, rare allele of 104 bp was seen in one sample, CEPH DNA \# 0201 , corresponding to a frequency of 0.006 . The PIC value of the EPO STR is 0.1824 in the CEPH parents, higher than that detected by SSCP in an unidentified population.

\section{Mapping Phkg}

Phkg and D5Mit27 were mapped in the recombinant inbred strain AKXL. This strain was derived by crossing AKR/J and $\mathrm{C} 57 \mathrm{~L} / \mathrm{J}$ and is therefore informative at $P h k g 4 C$ (Taylor 1989; Table 1; Fig. 1). The SDP of $P h k g$ in AKXL matched that of Fla and Gus, as did the SDP of D5Mit27, an STR which has recently been localized to Gus (Table 2; Winchester et al. 1987; Dietrich et al. 1992b). Fla and Gus previously defined the most distal SDP available on Chr 5 in AKXL; thus the candidate region for Phkg extended from $B c d-1$ to the telomere. Our determination of the SDP for Epo in AKXL excluded the most distal portion of Chr 5 (Table 2, Fig. 1).

To confirm this assignment, we mapped Phkg in an intersubspecific backcross. Eighty-nine backcross animals were typed for five STRs on distal Chr 5. Nineteen crossovers were detected between $A f p$ and $G u s$, four between Gus and Epo, and none between Gus, D5Mit27, and
Table 3. Segregation of Chr 5 loci in the backcross (DF/B-df/df $\times$ CASA/Rk) $\times$ $\mathrm{DF} / \mathrm{B}-d f / d f$. Each column represents a chromosome inherited from an $\mathrm{F}_{1}(\mathrm{DF} / \mathrm{B}-d f / d f$ $\times$ CASA/Rk) individual. Closed and open boxes represent DF/B and CASA/Rk alleles, respectively. The number of backcross animals that inherited each chromosome is indicated below.

\begin{tabular}{|c|c|c|c|c|c|c|}
\hline \multirow[b]{2}{*}{$A f p$} & \multicolumn{6}{|c|}{ Chromosomes } \\
\hline & $\square$ & $\mathbf{a}$ & $\boldsymbol{\square}$ & $\square$ & $\boldsymbol{0}$ & $\square$ \\
\hline Gus, D5Mit27, Phkg & $\square$ & $\mathbf{\square}$ & $\square$ & $\overline{\mathbf{n}}$ & $\overline{\mathbf{0}}$ & $\square$ \\
\hline Epo & $\square$ & $\mathbf{\square}$ & $\square$ & $\mathbf{\square}$ & $\square$ & $\bar{\square}$ \\
\hline Total animals: 89 & 37 & 29 & 12 & 7 & $\overline{2}$ & 2 \\
\hline
\end{tabular}

Phkg. No double recombinants were observed (Table 3). We estimate the distance between $A f p$ and $G u s$ to be 21.3 $\pm 4.3 \mathrm{cM}$. The $95 \%$ confidence interval is $11.3-31.3 \mathrm{cM}$, consistent with the published value of $19.7 \pm 2.8 \mathrm{cM}$ (Rothman and Ericson 1987; Geissler et al. 1988). The distance between $G u s$ and Epo was estimated to be $4.5 \pm 2.2$ $\mathrm{cM}$ with a $95 \%$ confidence interval of $0-14.3 \mathrm{cM}$, in agreement with the previously reported values of $8.4 \pm 2.0 \mathrm{cM}$ (Singh et al. 1991) and $5.6 \pm 2.2 \mathrm{cM}$ (Rosnet et al. 1993).

The human homolog of Phkg, PHKG, has not been cloned, and polymorphisms are unavailable. PHKG has been mapped to human $\mathrm{Chr} 7$ by Southern analysis of human-rodent somatic cell hybrid mapping panels with mouse or rabbit cDNA clones as probes (Chamberlain et al. 1987; Jones et al. 1990); both groups also observed cross-hybridizing sequences on Chrs 7 and 11 . In situ hybridization with a rabbit $\gamma$ Phk cDNA clone produced a strongly hybridizing signal at human Chr 7p11-p12 and weaker signals at 7q21 and 11p11-p14 (Jones et al. 1990). The authors concluded that PHKG is probably located near the centromere of $\mathrm{Chr} 7$; however, a cDNA probe might be expected to hybridize more strongly with a pseudogene than with the functional intron-containing gene. Linkage of Gus, Phkg, and Epo on distal mouse Chr 5 and the locations of GUSB and EPO on human 7q21-q22 (McAlpine et al. 1991) suggest 7q21-q22 as the likely location of PHKG.

Acknowledgments. We thank Sally Camper for kindly providing genomic DNA from intersubspecific backcross progeny, and Miriam Meisler and Margit Burmeister for helpful discussions. Supported by grants DK42718 and HG00209 from the National Institutes of Health, and by a grant from The March of Dimes Birth Defects Foundation.

\section{References}

Abbot, C. (1992). Characterization of mouse-hamster somatic cell hybrids by PCR: a panel of mouse-specific primers for each chromosome. Mammalian Genome 2, 106-109. 
Aitman, T.J., Hearne, C.M., McAleer, M.A., Todd, J.A. (1991). Mononucleotide repeats are an abundant source of length variants in mouse genomic DNA. Mammalian Genome 1, 206-210.

Allanson, I.E., Gemmill, R.M., Hecht, B.K., Johnsen, S., Wenger, D.A. (1988). Deletion mapping of the beta-glucuronidase gene. Am. J. Hum. Genet. 29, 517-522.

Barnard, P.J., Derry, J.M., Ryder-Cook, A.S., Zander, N.F., Kilimann, M.W. (1990). Mapping of the phosphorylase kinase alpha subunit gene on the mouse X chromosome. Cytogenet. Cell Genet. 53, 91-94.

Botstein, D., White, R.L., Skolnick, M., Davis, R.W. (1980). Construction of a genetic linkage map in man using restriction fragment length polymorphisms. Am. J. Hum. Genet. 32, 314-331.

Buckwalter, M.S., Katz, R.W., Camper, S.A. (1991). Localization of the panhypopituitary dwarf mutation $(d f)$ on mouse chromosome 11 in an intersubspecific backcross. Genomics 10, 515-526.

Cawley, K.C., Akita, C.G., Angelos, K.L., Walsh, D.A. (1993). Characterization of the gene for rat phosphorylase kinase catalytic subunit. J. Biol. Chem. 268, 1194-1200.

Chamberlain, J.S., VanTuinen, P., Reeves, A.A., Philip, B.A., Caskey, C.T. (1987). Isolation of CDNA clones for the catalytic gamma subunit of mouse muscle phosphorylase kinase: expression of mRNA in normal and mutant Phk mice. Proc. Natl. Acad. Sci. USA 84, 2886-2890.

Davidson, J.J., Ozcelik, T., Hamacher, C., Willems, P.J., Francke, U., Kilimann, M.W. (1992). cDNA cloning of a liver isoform of the phosphorylase kinase alpha subunit and mapping of the gene to Xp22.2p22.1, the region of human X-linked liver glycogenosis. Proc. Natl. Acad. Sci. USA 89, 2096-2100.

Dietrich, W., Katz, H., Lincoln, S.E., Shin, H.-S., Friedman, J., Dracopoli, N.C., Lander, E.S. (1992a). A genetic map of the mouse suitable for typing interspecific crosses. Genetics 131, 423 447 .

Dietrich, W., Miller, J., Katz, H., Joyce, D., Steen, R., Lincoln, S., Daly, M., Reeve, M.P., Weaver, A., Anagnostopoulos, P., Goodman, N., Dracopoli, N., Lander, E.S. (1992b). Genetic Maps (Cold Spring Harbor, N.Y.: Cold Spring Harbor Laboratory Press).

Francke, U., Darras, B.T., Zander, N.F., Kilimann, M.W. (1989). Assignment of human genes for phosphorylase kinase subunits alpha (PHKA) to Xq12-q13 and beta (PHKB) to 16q12-q13. Am. J. Hum. Genet. 45, 276-282.

Frankel, W.N., Stoye, J.P., Taylor, B.A., Coffin, J.M. (1989). Genetic identification of endogenous polytropic proviruses using recombinant inbred mice. J. Virol. 63, 3810-3821.

Geissler, E.N., Cheng, S.V., Gusella, J.F., Housman, D.E. (1988). Genetic analysis of the dominant white spotting $(W)$ region on mouse chromosome 5: identification of cloned DNA markers near $W$. Proc. Natl. Acad. Sci. USA 85, 9635-9639.

Harmann, B., Zander, N.F., Kilimann, M.W. (1991). Isoform diversity of phosphorylase kinase alpha and beta subunits generated by alternative RNA splicing. J. Biol. Chem. 266, 15631-15637.

Hearne, C.M., McAleer, M.A., Love, J.M., Aitman, T.J., Connall, R.J., Ghosh, S., Knight, A.M., Prins, J-B., Todd, J.A. (1991). Additional microsatellite markers for mouse genome mapping. Mammalian Genome $1,273-282$.

Hsieh, C.L., Navankasattusas, S., Escobedo, J.A., Williams, L.T., Francke, U. (1991). Chromosomal localisation of the gene for AA-type plateletderived growth factor receptor (PDGFRA) in humans and mice. $\mathrm{Cy}$ togenet. Cell Genet. 56, 160-163.

Human Gene Mapping 11 (1991). Cytogenet. Cell Genet. 58.

Jones, T. A., da Cruz, S., Spurr, N.K., Sheer, D., Cohen, P.T. (1990). Localisation of the gene encoding the catalytic gamma subunit of phos- phorylase kinase to human chromosome bands 7p12-q21. Biochim. Biophys. Acta 1048, 24-29.

Kozak, C.A., Stephenson, D.A. (1992). Mouse Chromosome 5. Mammalian Genome 3 (Suppl.), S65-S80.

Lin, F-K., Suggs, S., Lin, C-H., Browne, J.K., Smalling, R., Egrie, J.C., Chen, K.K., Fox, G.M., Martin, F., Stabinsky, Z., Badrawi, S.M., Lai, P-H., Goldwasser, E. (1985). Cloning and expression of the human erythropoietin gene. Proc. Nat1. Acad. Sci, USA 82, 7580-7584.

Lossie, A.C., Buckwalter, M.S., Camper, S.A. (1993). Lysyl oxidase (Lox) maps between Grl-1 and Adrb-2 on mouse Chromosome 18. Mammalian Genome 4, 177-178.

Maichele, A.J., Chamberlain, J.S. (1992). Cross-species conservation of a polymorphic dinucleotide repeat in the dystrophin gene. Mammalian Genome 3, 290-292.

Maichele, A.J., Farwell, N.J., Chamberlain, J.S. (1993). A B2 repeat insertion generates alternate structures of the mouse muscle gamma phosphorylase kinase gene. Genomics 16, 139-149.

McAlpine, P.J., Shows, T.B., Boucheix, C., Huebner, M., Anderson, W.A. (1991). The 1991 catalog of mapped genes and the report of the nomenclature committee. Cytogenet. Cell Genet. 58, 5-102.

McDonald, J.D., Lin, F-K., Goldwasser, E. (1986). Cloning, sequencing, and evolutionary analysis of the mouse erythropoietin gene. Mol. Cell. Biol. 6, 842-848.

Nojima, H. (1989). Structural organization of multiple rat calmodulin genes. J. Mol. Biol. 208, 269-282.

Orita, M., Sekiya, T., Hayashi, K. (1990). DNA sequence polymorphisms in Alu repeats. Genomies 8, 271-278.

Picket-Gies, C.A., Walsh, D.A. (1986). Phosphorylase kinase. In The Enzymes, 3rd ed., P.D. Boyer, E.G. Krebs, eds. (Orlando: Academic Press). pp. 395-459.

Rosnet, O., Stephenson, D., Mattei, M.-G., Marchetto, S., Masabumi, S., Chapman, V.M., Birnbaum, D. (1993). Close physical linkage of the FLTI and FLT3 genes on chromosome 13 in man and chromosome 5 in mouse. Oncogene 8, 173-179.

Rothman, E.D., Ericson, W.A. (1987). Statistics: Methods and Applications, 2nd ed. (Dubuque, Iowa: Kendall/Hunt), pp. 374-375.

Singh, G., Kuar, S., Stock, J.L., Jenkins, N.A., Gilbert, D.J., Copeland, N.G., Potter, S.S. (1991). Identification of 10 murine homeobox genes. Proc. Natl. Acad. Sci. USA 88, 10706-10710.

Taylor, B.A. (1989). Recombinant inbred strains. In Genetic Variants and Strains of the Laboratory Mouse, 2nd ed., M.F. Lyon, A.G. Searle, eds. (New York: Oxford University Press), pp. 773-796.

Theune, S., Fung, J., Sakaguchi, Y., Naylor, S.L. (1991). PCR primers for human chromosomes: reagents for the rapid analysis of somatic cell hybrids. Genomics 9, 511-516.

Watkins, P.C., Eddy, R., Hoffman, N., Stanislovitis, P., Beck, A.K., Galli, J., Vellucci, V., Gusella, J.F., Shows, T.B. (1986). Regional assignment of the erythropoietin gene to human chromosome region 7pter-q22. Cytogenet. Cell Genet. 42, 214-218.

Weber, J.L., May, P.E. (1989). Abundant class of human DNA polymorphisms which can be typed using the polymerase chain reaction. Am. J. Hum. Genet. 44, 388-396.

Winchester, G., Lynes, M.A., Taylor, B.A. (1987). The structural gene for F liver protein (Flp) maps to chromosome 9 of the mouse. Immunogenetics $26,356-358$.

Zander, N.F., Meyer, H.E., Hoffmann-Posorske, E., Crabb, J.W., Heilmeyer, L.M., Jr., Kilimann, M.W. (1988). cDNA cloning and complete primary structure of skeletal muscle phosphorylase kinase (alpha subunit). Proc. Natl. Acad. Sci. USA 85, 2929-2933. 